\title{
Primary herpetic gingivostomatitis pada individu dewasa muda Primary herpetic gingivostomatitis in young adult
}

\author{
${ }^{1}$ Erni Marlina, ${ }^{2}$ Hadi Soenartyo \\ ${ }^{1}$ Program Pendidikan Dokter Gigi Spesialis Ilmu Penyakit Mulut \\ ${ }^{2}$ Departemen Ilmu Penyakit Mulut \\ Fakultas Kedokteran Gigi Universitas Airlangga \\ Surabaya, Indonesia
}

\begin{abstract}
Primary herpetic gingivostomatitis (PHGS) is a disease of primary infection with herpes simplex virus type I, which is often infects children and late adolescents. However, the disease could affect adults, too. This report aims to discuss the diagnosis and treatment of a young adult suffered PHGS which is previously diagnosed as pericoronitis. A patient, 24-year-old man, working in the private sector, complained of pain on the gingiva at the posterior wisdom mandibular teeth, accompanied with pain on pharyng and labium ulceration that did not heal even the patient took drugs from public health centre. Patient was prescribed acyclovir $200 \mathrm{mg} 5$ times a day, mouthwash containing anasteticum, systemic analgesics, and vitamins. The ulceration healed 2 days later. It was concluded that despite PHGS occurs commonly in children, but the adult could suffer this disease, and detailed anamnesis along with intraoral and extraoral examination are the main key for accurate diagnosis and therapy.
\end{abstract}

Keywords: primary herpetic gingivostomatitis, herpes virus, stomatitis

\begin{abstract}
ABSTRAK
Primary herpetic gingivostomatitis (PHGS) merupakan penyakit infeksi virus herpes simpleks primer tipe I yang sering dijumpai pada anak dan remaja masa pubertas akhir. Meski demikian, penyakit ini dapat mengenai orang dewasa. Laporan kasus ini bertujuan untuk membahas diagnosis dan tatalaksana kasus PHGS yang terjadi pada dewasa muda yang awalnya didiagnosis sebagai perikoronitis. Seorang pasien, laki-laki, berusia 24 tahun, bekerja di bidang swasta, datang dengan keluhan sakit di gingiva kanan dan kiri paling belakang, disertai rasa nyeri tenggorokan dan stomatitis di bibir yang tidak hilang meskipun telah diberikan obat dari puskesmas. Sebagai penatalaksanaannya, pasien diterapi antivirus acyclovir $200 \mathrm{mg} 5 \mathrm{kali}$ sehari, obat kumur yang mengandung anastetikum, analgesik sistemik, dan vitamin. Pasien sembuh 2 hari kemudian. Dapat disimpulkan bahwa PHGS meski sering terjadi pada anak, namun bisa juga terjadi pada orang dewasa. Oleh karena itu anamnesis serta pemeriksaan yang teliti merupakan kunci untuk menegakkan diagnosis yang tepat sehingga pasien dapat diterapi dengan tepat pula.
\end{abstract}

Kata kunci: primary herpetic gingivostomatitis, virus herpes, stomatitis

Koresponden: Erni Marlina, Bagian Ilmu Penyakit Mulut Fakultas Kedokteran Gigi Universitas Hasanuddin. Jl. Kandea No.5 Makassar 90135, Indonesia.E-mail: e.marlina@yahoo.co.id

\section{PENDAHULUAN}

Primary herpetic gingivostomatitis (PHGS) merupakan penyakit infeksi virus herpes simpleks primer tipe I yang umumnya sering dijumpai pada anak dan remaja masa pubertas akhir. ${ }^{1}$ Gejala khasnya berupa demam yang muncul tiba-tiba, anoreksia, nyeri iritasi dan nyeri yang intens pada rongga mulut. Selanjutnya, akan disertai timbulnya lesi di dalam rongga mulut baik pada permukaan mukosa bergerak maupun tidak bergerak. Lesi awal berupa vesikula yang dengan cepat akan pecah, menyatu sehingga membentuk ulserasi besar yang sangat perih. Selanjutnya, gingiva menjadi eritema dan lunak. ${ }^{2}$

Umumnya, penyakit PHGS terjadi pada anak dan remaja akhir, insidensinya pada anak hingga usia 5 tahun adalah $33 \%$, sedang pada masa remaja akhir insidensi infeksi ini mencapai 70-80\%. ${ }^{1}$ Akan tetapi, infeksi ini terkadang juga dijumpai pada orang dewasa, misalnya yang dilaporkan terjadi pada seorang pasien berusia 70 tahun. ${ }^{3}$

Pada artikel ini akan dilaporkan dan dibahas mengenai diagnosis dan penatalaksanaan kasus pada pasien dewasa muda yang menderita infeksi herpetic gingivostomatitis.

\section{KASUS}

Pada tanggal 9 Oktober 2009, seorang lakilaki berusia 24 tahun datang ke Klinik Bagian Ilmu Penyakit Gigi Mulut Universitas Airlangga dengan keluhan sariawan sejak satu minggu yang lalu. Riwayatnya dua hari sebelum munculnya sariawan, pasien mengalami demam, nyeri tenggorokan dan gigi kanan paling belakang rahang bawah terlihat gingivanya seperti sobek dan terasa nyeri. Selain itu, juga terasa nyeri di gingiva bagian belakang gigi rahang atas depan. Besoknya, muncul sariawan di bagian bibir rahang atas dan rahang bawah, yang 
akhirnya menjadi krusta (Gambar 1). Pasien kemudian berobat ke Puskesmas dan diberikan $\mathrm{OBH}$, amoxycillin, dan vitamin B comp, serta CTM. Setelah obatnya tuntas, ternyata tidak ada perubahan, sehingga pasien kembali ke Puskesmas dan diberi obat yang sama. Obat tuntas tetapi belum juga ada perubahan.

Riwayat kesehatan umum tidak ada kelainan, pasien tidak ada riwayat stomatitis, juga tidak ada riwayat alergi. Pasien sebelumnya tidak pernah mengkonsumsi obat-obatan yang tidak semestinya. Sepanjang ingatan pasien, dia belum pernah terkena infeksi virus.

Pada pemeriksaan ekstraoral nampak krusta kering, kasar, masih berdarah disertai lesi ulserasi dengan pseudomembran putih kekuningan dengan diameter sekitar $5 \mathrm{~mm}$ di labium atas, sedangkan di labium bawah krusta kering, kasar, berwarna kemerahan dengan sekitar 7 lesi ulserasi diameter 0,2-4 mm. Pemeriksaan kelenjar submandibularis kiri tidak ada kelainan, sedang yang kanan terasa nyeri dan teraba keras.

Pada pemeriksaan intraoral nampak edema dengan pus yang keluar jika ditekan pada daerah gingivopalatal gigi anterior. Pada gigi molar ketiga kanan rahang bawah nampak peradangan di sekitar gigi tersebut, juga tampak lesi ulserasi dengan pseudomembran putih kekuningan di daerah retromolar pad dengan diameter sekitar $3 \mathrm{~mm}$.
Dengan memperhatikan riwayat dan gambaran klinis, pasien didiagnosis sebagai primary herpetic gingivostomatitis dengan diagnosis banding erythema multiforme.

\section{PENATALAKSANAAN KASUS}

Prinsip terapi yang akan dilakukan adalah kausatif, simptomatis dan suportif, serta preventif. Untuk maksud tersebut, pasien kemudian diberikan acyclovir $200 \mathrm{mg} 5$ kali sehari untuk 5 hari sebagai kausatif, diberikan asam mefenamat sebanyak 15 tablet untuk diminum hanya jika terasa nyeri, dan benzydamin $\mathrm{HCl}$ kumur 4 kali sehari sebagai terapi simptomatis. Vitamin B complex sebagai terapi suportif, serta edukasi pasien bahwa pasien sedang dalam masa infeksius sehingga disarankan untuk menghindari kontak intim dengan orang lain. Pasien diminta untuk kontrol tiga hari kemudian.

Pada kontrol tiga hari kemudian, pasien tidak lagi mempunyai keluhan. Pemeriksaan intraoral maupun ekstraoral tidak ada lagi kelainan (gambar 2). Semua terapi yang diberikan pada kunjungan sebelumnya tetap dilanjutkan.

\section{PEMBAHASAN}

Meskipun PHGS sering dijumpai pada anak dan remaja akhir, namun penyakit ini juga dapat mengenai orang dewasa. Hal ini seperti yang dilaporkan oleh MacPhail ${ }^{3}$ mengenai kasus PHGS
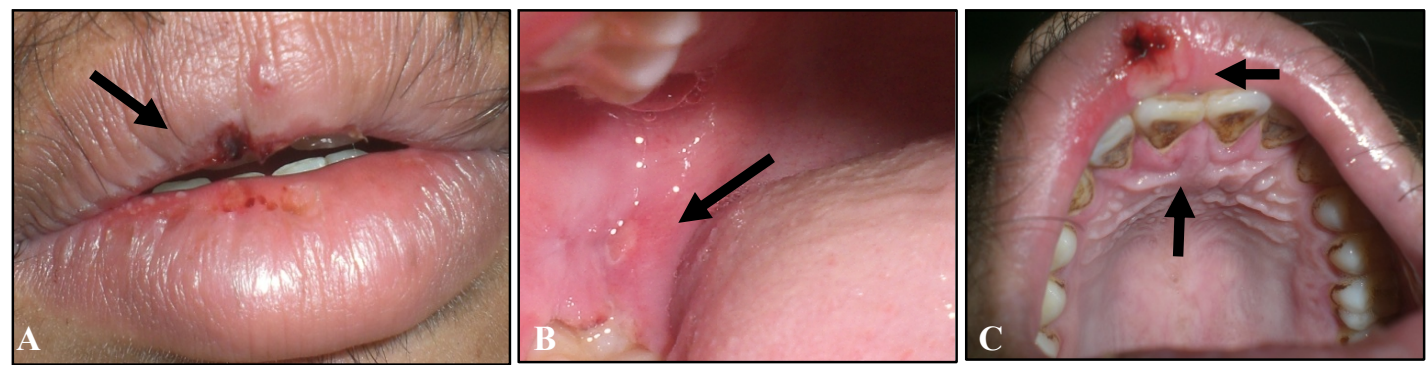

Gambar 1 Pada kunjungan pertama; A krusta, ulserasi di labium atas dan bawah, B ulserasi di retromolar pad kanan, $\mathrm{C}$ peradangan di palatogingiva anterior rahang atas, berkrusta dan ulserasi.
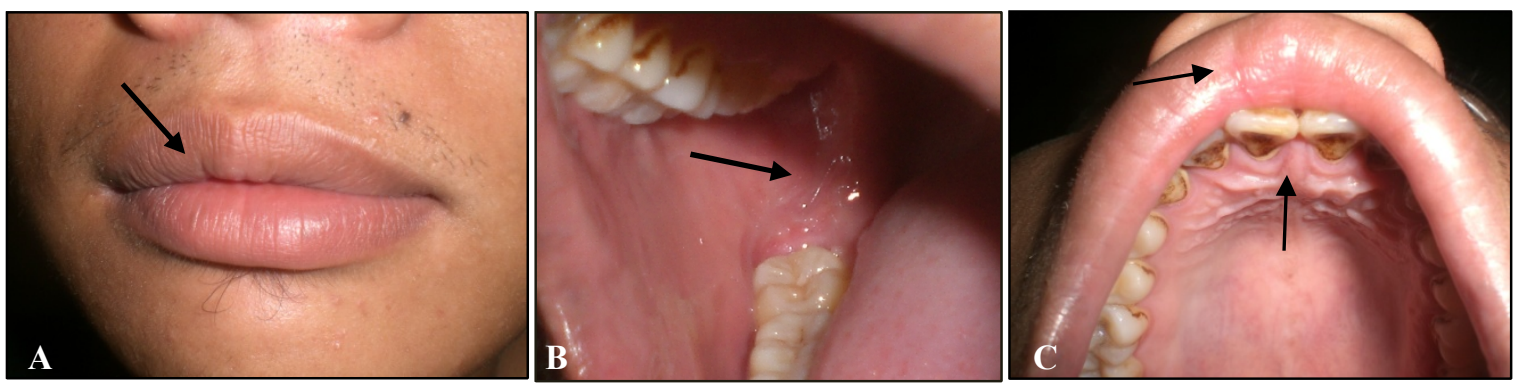

Gambar 2 Kontrol pertama; A krusta dan ulserasi di bibir sembuh, B lesi di retromolar pad sembuh, C peradangan di palatogingiva gigi anterior rahang atas berkurang, krusta dan ulserasi di labium rahang atas sembuh. 
terjadi pada lansia berumur 70 tahun, dan laporan Treister $^{2}$ mengenai kasus PHGS pada orang dewasa berusia 50 tahun. Infeksi virus Herpes simplex (VHS) pada orang dewasa dapat bermanifestasi sebagai faringotonsilitis, dengan lesi yang terbatas hanya pada tonsil palatinalis dan orofaring posterior, disertai dengan gejala rasa terbakar pada kerongkongan, demam, malaise dan sakit kepala. ${ }^{2}$

Terjadinya penyakit PHGS pada orang dewasa kemungkinan disebabkan oleh dua hal, pertama oleh karena pasien belum pernah terpapar oleh VHS sehingga belum memiliki titer antibodi di dalam tubuhnya. Hal tersebut menyebabkan jika pada masa dewasanya pasien sedang dalam kondisi imunosupresi, maka VHS dapat menginfeksi dan menimbulkan manifestasi. ${ }^{2}$ Kedua, infeksi VHS kemungkinan disebabkan oleh jenis virus yang lain, infeksi oleh satu jenis tertentu tidak memproteksi terhadap jenis yang lain. ${ }^{3}$

Pada pasien muda, diagnosis klinis PHGS biasanya ditegakkan berdasarkan adanya tanda dan gejala klinis yang khas, ${ }^{1,4}$ terutama jika dijumpai adanya tanda klasik berupa lesi vesikulaulseratif oral atau perioral disertai gejala prodromal dan lesi di daerah keratinisasi seperti pada palatum dan gingiva. ${ }^{2,4-6}$ Akan tetapi, pada orang dewasa riwayat medis dan riwayat infeksi serta pemeriksaan penunjang lain perlu dilakukan. ${ }^{2}$

Pada kasus ini, pasien didiagnosis PHGS berdasarkan riwayat prodromal, demam dan nyeri tenggorokan sebelum munculnya peradangan gingivopalatal gigi anterior rahang atas, serta peradangan gingiva di daerah molar ketiga serta adanya lesi ulserasi di daerah retromolar pad yang merupakan daerah keratinisasi. Adanya krusta yang kering dan kasar, dan perdarahan di labium atas dan bawah juga menjadi tanda khas infeksi ini. Gambaran tersebut merupakan tanda klasik PHGS yang pada saat pertama kali pemeriksaan langsung dapat mengarah pada diagnosis PHGS. Akan tetapi, pada pasien ini muncul keraguan, oleh karena usianya sudah memasuki masa dewasa muda sementara PHGS lebih sering terjadi pada usia di bawah 10 tahun. ${ }^{2}$ Selain itu, juga ada kemungkinan pasien tidak mengingat masa terjadinya infeksi VHS primer atau orangtua pasien tidak menyadari infeksi primer tersebut karena infeksi primer sering terjadi secara subklinis. ${ }^{2}$ Karena itu, pada kasus ini pasien dianggap mengalami PHGS sebagai manifestasi primer atau infeksi sekunder dengan manifestasi yang parah atau berbeda dari biasanya.

Tidak dilakukannya pemeriksaan penunjang oleh karena tanda dan gejala yang khas dapat dijumpai, serta pemeriksaan penunjang yang bisa dilakukan sangat terbatas baik dari segi waktu maupun untuk biaya. Misalnya, untuk swab meskipun hasilnya menunjukkan adanya VHS pada daerah yang di-swab namun belum tentu penyebab lesi atau keluhan pasien adalah infeksi VHS. Kultur tidak dapat dilakukan oleh karena diperlukan spesimen vesikula pecah yang masih segar, sementara vesikula sangat jarang dijumpai oleh karena cepat mengalami rupture. Selain itu metode ini tidak dapat membedakan antara infeksi primer maupun sekunder. Titer antibodinya tidak dapat dijumpai hingga minimal 1 minggu setelah masa akut, atau mencapai puncaknya setelah 3-4 minggu, dengan kemungkinan terjadinya false positif jika hasil pemeriksaan darah pasien pada saat pertama kali pemeriksaan menunjukkan hasil seropositif. Sedangkan pemeriksaan PCR meskipun akurat dan tidak membutuhkan spesimen segar namun perlu biaya yang relatif mahal. ${ }^{1,4}$ Sementara dalam kasus ini pasien sudah mengalami rasa nyeri lebih dari seminggu sehingga diperlukan tindakan yang cepat dan tepat. Oleh karena itu pasien diterapi dengan memastikan infeksinya disebabkan oleh VHS.

Diagnosis banding PHGS adalah erythema multiforme, namun pasien tidak mengkonsumsi obat-obat atau zat lain yang bisa dicurigai sebagai pemicu terjadinya erythema. Selain itu, pada erythema multiforme tidak dapat dijumpai lesi pada daerah keratinisasi, dan tidak dijumpai pula adanya lesi target yang merupakan tanda khas., ${ }^{2,6}$

Pasien kemudian diberikan acyclovir $200 \mathrm{mg}$ dengan dosis 5 kali sehari selama 5 hari. Umumnya kepustakaan mengindikasikan bahwa pemberian acyclovir hanya efektif jika diberikan dalam rentang waktu 72 jam sejak terjadinya vesikula. Namun dalam kasus ini acyclovir tetap diberikan berdasarkan sifatnya, yaitu analog acyclic purine nucleoside yang pada awalnya difosforilasi oleh thymidine kenase virus, selanjutnya difosforilasi kembali oleh enzim selular host. Analog ini secara kontinyu mengikat dan menghambat polimerase virus DNA yang mengakibatkan terminasi elongasi rantai sehingga menghasilkan penghambatan virus. ${ }^{2,6-10}$ Dengan demikian pemberian acyclovir pada pasien yang telah mengalami munculnya lesi sejak 7 hari yang lalu, tidak dimaksudkan untuk menyembuhkan sel yang telah terkontaminasi namun lebih kepada upaya mencegah penyebaran virus tersebut. Selain itu, diharapkan juga bahwa dengan pemberian acyclovir ini, episode akutnya berlangsung lebih singkat sehingga menurunkan rasa nyeri yang ditimbulkan oleh karena infeksi primer yang biasanya merupakan kasus yang paling berat. $^{7-9}$ 
Asam mefenamat diberikan sebagai terapi simptomatis secara sistemik, sedang benzydamine $\mathrm{HCl}$ sebagai terapi simptomatis lokal untuk mengatasi rasa nyeri. Vitamin B comp diharapkan dapat membantu meningkatkan daya tahan tubuh pasien melalui kecukupan asupan vitamin yang dibutuhkan sehingga dapat dicegah terjadinya gangguan metabolik fungsional yang menyebabkan berkurangnya asupan vitamin. ${ }^{10}$

Edukasi tercakup dalam upaya preventif, yaitu pasien diinformasikan mengenai kondisinya yang infeksius sehingga diharapkan pasien mengisolasi diri dari anggota keluarganya ataupun orang lain. Selanjutnya pasien diinformasikan pula untuk mengkonsumsi makanan tinggi kalori tinggi protein untuk membantu upaya penyembuhan.

Pada hari ketiga sejak kunjungan pertama, pasien tidak mempunyai keluhan lagi. Hal tersebut menunjukkan respon yang cepat dari terapi yang diharapkan Selain karena infeksi PHGS adalah penyakit yang self limiting, terapi dan daya tahan tubuh pasien sendiri sangat membantu dalam mempercepat redanya gejala dan tanda penyakit.

Berdasarkan pembahasan sebelumnya, dapat disimpulkan bahwa meskipun PHGS sering terjadi pada anak, namun bisa juga terjadi pada orang dewasa. Oleh karena itu, anamnesis yang teliti merupakan kunci untuk menegakkan diagnosis yang tepat sehingga pasien dapat diterapi dengan tepat juga.

Pada kasus ini tidak dilakukan pemeriksaan laboratorium selain karena tanda dan gejala yang khas, namun juga karena pemeriksaan penunjang yang bisa dilakukan relatif membutuhkan waktu dan biaya yang relatif mahal. Akan tetapi bila kondisi memungkinkan, pasien tetap disarankan untuk melakukan pemeriksaan penunjang sehingga diagnosis dapat didukung dengan akurat, serta untuk memastikan jenis virus penyebab munculnya keluhan, serta sumber penyebaran virus.

\section{DAFTAR PUSTAKA}

1. Fatahzadeh M, Schwartz AR. Human herpes simplex virus infection: epidemiology, pathogenesis, symptomatology diagnosis and management. J Am Acad Dermatol 2007; 17: 5.

2. Treister SN, Lerman AM. Acute oral ulceration. J Am Dent Assoc 2007;138;499-501.

3. MacPhail L, Greenspan D. Herpetic gingivostomatitis in a 70-year old man. Oral Surg Oral Med Oral Pathol Oral Radiol Endod 1995; 79(1):50-2.

4. Greenberg SM. Ulserative, vesicular and bullous lesions. In: Lynch AM, Vernon BJ, Greenberg SM. Burket: Ilmu penyakit mulut. $8^{\text {th }}$ Ed. Jakarta: Bina Rupa Aksara; 2003. p. 52-4.

5. Haaheim RL, Pattison RJ, Whitley RJ. A practical guide to clinical virology. $2^{\text {nd }}$ Ed. John Wiley and Son LTD; 2003.

6. Field A, Longman L. Mucocutaneous disease and connective tissue disorders. In Field A, Longman L, Tyldesley RW. Tyldesley's oral medicine. $5^{\text {th }}$ Ed. London: Oxford University Press; 2003. p.41-2.

7. Blevis JY. Primary herpetic gingivostomatitis in young children medical management. Available at www.medscape.com. Diakses tanggal 12 Juli 2009.

8. Rubsamen H, Weigmann, Deres K. Viral infection and treatment. Marcell Decker Inc.; 2003.

9. DeRossi SS, Salazar G, Sarin J, Alawi F. Chronic lesion of the gingivae and mucosa. J Am Dent Assoc 2007; 138; 1589-92.

10. Ball GFM. Vitamins and they role in human body. Blackwell publishing; 2004.p.8-12. 